\title{
Program Arabic Club dalam Meningkatkan Komunikasi-Produktif Bahasa Arab Santri MTs Qudsiyah Putri
}

\author{
Ihsan \\ IAIN Kudus, Jawa Tengah, Indonesia \\ Ihsandr12@yahoo.co.id
}

\begin{abstract}
Arabic Club Program in Improving Arabic Language Communication-Productive of MTs Qudsiyah Putri Students. This article aims to determine the ability of students in Arabic communication-poductive through the Arabic Club program. Besides that it is also to find out the application of the Arabic Club program and its supporting and inhibiting factors. The method used is descriptive qualitative. In this study the researcher as a human instrument serves to establish the focus of research, select informants as sources of data, collect data, examine data quality, analyze data, interpret data and make conclusions. The results obtained from this study are as follows; 1) an increase in students' language-productive communication skills in learning Arabic. This ability arises because students feel confident and motivated to learn Arabic in formal classes after attending the Arabic Club program, 2) the program is implemented with the principle of learning that is easy and fun but still secure learning objectives or can be called effective learning, 3) factors supporters are internal from students and external, while the obstacles found are external students.
\end{abstract}

Keywords : Arabic Club, Communication-Productive

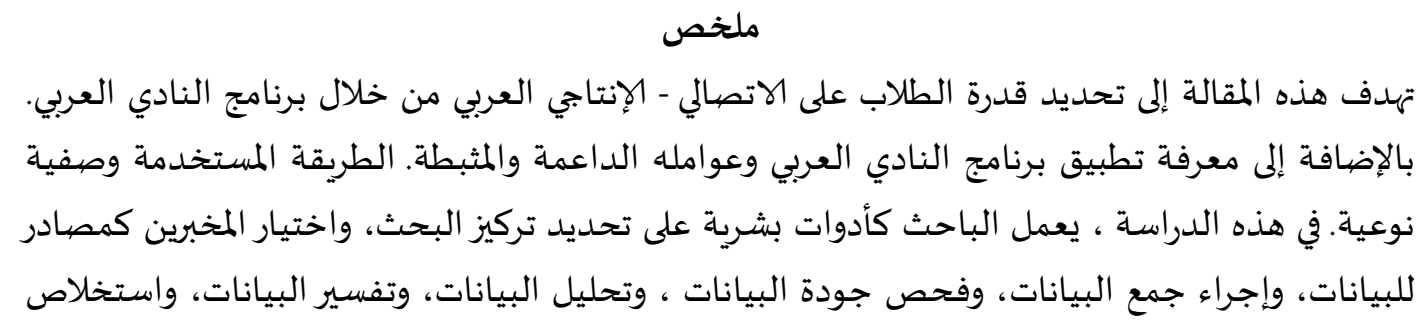




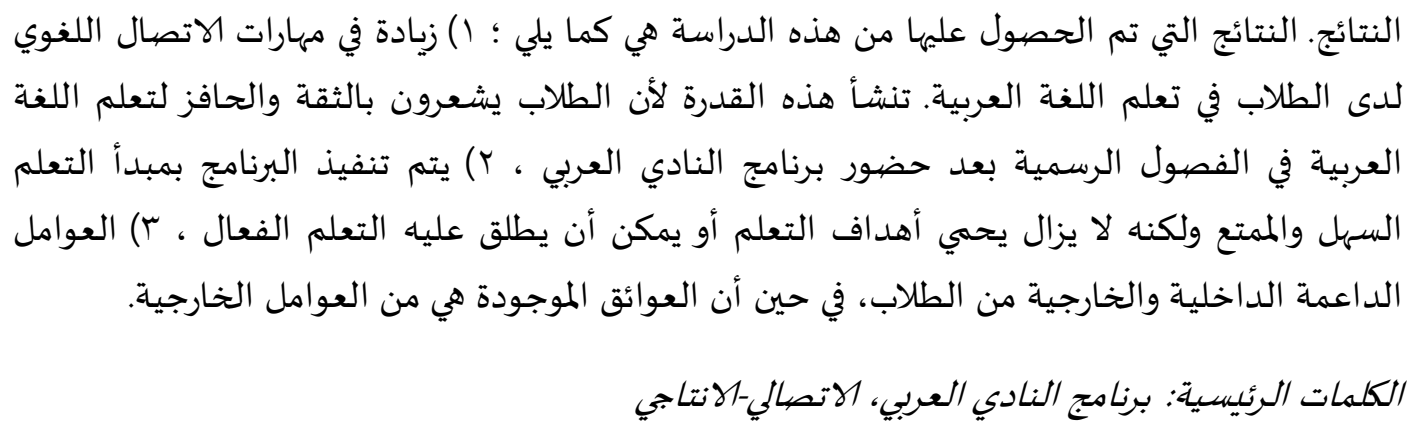

\begin{abstract}
Abstrak
Artikel ini bertujuan untuk mengetahui kemampuan siswa dalam penguasaan komunikasi-poduktif bahasa Arab melalui program Arabic Club. Disamping itu juga untuk mengetahui penerapan program Arabic Club serta faktor perdukung dan penghambatnya. Metode yang digunakan adalah kualitatif deskriptif. Dalam penelitian ini peneliti sebagai human instrument berfungsi untuk menetapkan fokus penelitian, memilih informan sebagai sumber data, melakukan pengumpulan data, meneliti kualitas data, analisis data, menafsirkan data dan membuat kesimpulan. Hasil yang di dapat dari penelitian ini adalah sebagai berikut; 1) adanya peningkatan kemampuan komunikasi-produktif bahasa siswa pada pembelajaran bahasa Arab. Kemampuan ini muncul sebab siswa merasa percaya diri dan termotivasi untuk belajar bahasa Arab di kelas formal setelah mengikuti program Arabic Club, 2) program ini dilaksanakan dengan prinsip belajar yang mudah dan menyenangkan tetapi tetap mengutamankan tujuan pembelajaran atau bisa disebut pembelajaran yang efektif, 3) faktor pendukung bersifat internal dari siswa dan ekternal, sedang penghambat yang ditemukan bersifat eksternal siswa.
\end{abstract}

Kata kunci: program Arabic Club, Komunikasi-Poduktif

\title{
Pendahuluan
}

Bahasa Arab pada era modern sejajar dengan bahasa internasional yang resmi digunanakan oleh PBB. Pengakuan ini didasarkan oleh jumlah penutur bahasa Arab yang mencapai lebih dari 200 juta. Selain bahasa Arab sebagai bahasa resmi PBB secara berurutan adalah bahasa Inggris, China, Prancis, dan Spanyol. Peminatan terhadap bahasa ini semakin berkembang seiring berkembangnya pusat studi Islam dan Arab di penjuru dunia. Puasat studi Islam dan Arab tidak hanya berada di semenanjung Jazirah Arabiah atau negara Timur 
Tengah saja, bahkan sampai pada negara Barat. Ini yang menjadikan bahasa Arab sekarang bukan sekedar bahasa Agama melainkan juga bahasa komunikasi, budaya, dan sosial.

Melihat kondisi seperti itu, bahasa Arab merupakan bahasa yang telah mencapai puncak kedewasaan dan kematangan. Hal ini dibuktikan bahwa bahasa arab mampu menampung kebutuhan penggunanya dan menyerap berbagai perkembangan ilmu pengetahuan dan teknologi dalam berbagai bidang. Hal tersebut antara lain disebabkan oleh karakteristik bahasa Arab yang bersifat elastis, menganut sistem alanogi (qiyas) serta kaya akan perbendaharaan kata (mufrodat) dan kaya akan derivasi (istiqoq) (Rosyidi \& Mamlu'atun Ni'mah 2012).

Menurut Muhbib Abdul Wahab (2008) memerinci ciri khas yang menjadi suatu kelebihan bahasa Arab yang tidak dimiliki oleh bahasa lain, diantaranya; jumlah abjad sebanyak 24 huruf; I'rob, sesuatu yang mewajibkan keberadaan akhir kata pada keadaan tertentu; notasi syair (ilmu 'arudl); bahasa pasaran ('ammiyah) dan bahasa baku (fushah); huruf dhod yang tidak terdapar pada makhroj bahasa lain; perubahan kata kerja dan gramatikal disesuaikan dengan subjek; tidak ada kata yang bersyakal yang sulit dibaca; tidak ada kata yang tersusun dari dua huruf mati secara langsung; sedikit sekali kata-kata yang terdiri dari dua huruf (al-alfadz al-tsunaiyyah); tidak adanya empat huruf yang berharakat secara terus menurus.

Disamping memiliki banyak kelebihan seperti dipaparkan di atas, pada waktu yang sama akan menjadi kendala bagi pelajar, dikarenakan taraf kerumitan yang pada akhirnya muncul kesulitan dalam proses pembelajaran dan pengajaran. Untuk itu dibutuhkan suatu model pembelajaran yang mampu memberikan solusi untuk meminimalisir kesulitan yang dihadapi siswa dengan tanpa mengurangi ciri khas yang ada dalam bahasa Arab. Dengan adanya model pembelajaran bahasa ini dapat digunakan di lembaga formal atau lembaga nonformal yang memang konsen pada pembelajaran bahasa Arab.

Salah satu Madrasah yang memiliki konsen dalam mengembangkan kemampun bahasa Arab adalah MTs Qudsiyyah Putri. Madrasah ini merupakan pengembangan dari madrasah Qudsiyyah yang notabennya adalah madrasah yang semua siswa dan guru berjenis kelamin laki-laki dan termasuk madrasah tertua serta bercirikan salaf di kabupaten Kudus. Madrasah Qudsiyyah Putri lahir dikarenakan banyak permintaan dari masyarakan yang berkeinginan anak putrinya mendapat pengetahuan yang sama dalam bidang ilmu salaf. Yang 
membedakan madrasah ini dengan madrasah putri yang lain di lingkungan kabupaten Kudus dengan mengharuskan semua siswinya berada di asrama. Model madrasah putri seperti ini diharapkan akan muncul generasi putri yang soleh, berjiwa salafiyah serta mandiri.

Disamping alasan di atas, menurut Dr Abdul Jalil wakil sekertaris yayasan pendidikan Qudsiyyah, bahwa pendirian Madrasah Qudsiyyah Putri dengan mengembangkan semangat "Gusjigang" (bagus, ngaji, dagang) yang sering luput dengan kata gender. Dalam sejarah rokok kretek di Kudus dimulai oleh sosok perempuan yang bernama Ibu Nasilah. Secara kultur dan bisnis nama tersebut tertutupi dengan gender laki-laki. Untuk mengembalikan jati diri "gusjigang" agar tidak luput dari kata gender, maka yayasan pendidikan Qudsiyyah membuka pondok pesantren putri untuk mencetak generasi putri yang mempunyai kapasitas yang sama dengan santri putra.

Program yang diterapkan pondok pesantren ini tidak jauh beda dengan program yang diterapkan pada Madrasah Qudsiyyah Putra, baik dari segi konsentrasi, standart input dan output serta ditambah materi khusus perempuan. Sebagai contoh program pendidikan yang diterapkan di pondok pesantren ini diantaranya; i'dad ilmu tafsir, dengan orientasi pada pembekalan ilmu tafsir dasar bagi peserta didik. Dalam rangka mencapai program tersebut, standart yang digunakan adalah santri wajib hafal 1000 bait Alfiyah, fasih membaca al-Quran 30 juz, dan mampu membaca kitab fiqh an-Nisa'.

Dilihat dari muatan pendidikan yang ada di pondok pesantren ini, bahasa Arab memiliki posisinya urgent dalam menunjang keberlangsungan proses belajar mengajar. Posisi ini yang membuat pengasuh pondok pesantren pada umumnya dan khususnya guru bahasa Arab memiliki semangat menghantarkan para santriwatinya untuk bisa menguasahi bahasa Arab. Penguasaan bahasa dari segi ketrampilan meliputi penguasaan bersifat reseptif dan produktif serta penguasaan bahasa dari segi unsur atau gramatikalnya. Usaha yang dilakukan oleh pengurus dan guru dalam rangka meningkatkan kemampuan bahasa Arab santriwati dalam bentuk intra kurikuler dan ekstra kulikuler. Bentuk ekstra dalam menunjang kemampuan bahasa Arab di pondok pesantren ini adalah Arabic Club.

Dari latar belakang di atas, peneliti bermaksud ingin mengetahui bagaimana kemampuan bahasa Arab siswa pondok pesantren Qudsiyyah Putri dan bagaimana pelaksanaan program Arabic Club yang diterapkan di MTs 
Qudsiyyah Putri dan faktor pendukung serta penghambat dari pelaksanaan program tersebut. Sebagai sebuah program maka perlu kiranya untuk diketahui faktor pendukung dan penghambat dalam pelaksanaanya.

\section{Kajian Teori}

\section{Prinsip Pembelajaran Bahasa}

Secara umum bahasa memiliki karakteristik general dan secara khusus bahasa memiliki sifat yang unik. Keunikan ini yang membedakan antara bahasa satu dengan yang lainnya, terlebih bahasa Arab. Perbedaan ini, meliputi materi yang terkandung di dalam bahasa tersebut, pola tata bahasa untuk memahami kalimat atau wacana yang digunakan, dan memiliki keluasan makna. Dari segi fonologi bahasa Arab memiliki satu bentuk suara atau makhroj yakni ض (dhoh) yang tidak dimiliki oleh bahasa lain.

Dari karakteristik yang berbeda dengan bahasa lainnya, maka untuk mencapai keberhasilan pembelajaran dibutuhkan akan pemahaman prinsipprinsip pembelajaran bahasa Arab. Ada empat prinsip pembelajaran bahasa, yakni prioritas (al-uluwyyat), korektisitas (ad-diqqoh), bertahap (ad-darjiyyah), dan kerinduan belajar (at-tasywiq) (Rosyidi, 2012).

a. Prioritas (al-uluwyyat)

Dalam penyampaian pembelajaran bahasa, prinsip prioritas meliputi; pertama mendengar, berbicara, membaca, kemudian menulis; kedua mengajarkan kalimat terlebih dahulu sebelum mengajarkan kata; ketiga menggunakan kata-kata yang sering digunakan dalam percakapan sehari-hari sebelum menggunakan kata-kata sesuai dengan netive bahasa Arab.

Pembelajaran bahasa (language learning) dengan prinsip proritas disesuaikan dengan asumsi perolehan bahasa (language acquision). Dalam teori perolehan bahasa, bahwa anak akan memulai perkembangan bahasanya diawali dengan proses mendengar dan memperhatikan kemudian menirukan. Kemampuan anak dalam mendengar dan memperhatikan harus mendapat proritas yang pertama sebelum kemampuan berbicara atau menirukan, lalu kemampuan yang lain seperti membaca dan menulis. 
b. Korektisitas (ad-diqqoh)

Prinsip korektisitas ini dapat diterapkan pada pembelajaran unsur bahasa yang meliputi fonemik (أأصوات), morfologi dan sintaksis (التراكب), dan semantik (الدلالة/المعاني). Prinsip ini bermaksud guru mampu membetulkan ketika ada kesalahan dalam penggunaan unsur bahasa dan juga bisa mendorong siswa agar bisa kritis terhadap hal-hal berikut; korektisitas dalam pengajaran fonemik, korektisitas dalam pembelajaran sintaksis, dan korektisitas dalam pembelajaran semantik.

Pertama, korektisitas pengajaran fonemik berlangsung pada saat pembelajaran mendengar dan berbicara. Untuk meminimalisir pengucapan atau pelafalan bahasa Ibu pada bahasa Arab oleh siswa, guru menekankan untuk memperbanyak latihan mendengar dan pengucapan bunyi bahasa Arab yang semestinya secara terus-menerus. Disamping itu juga, guru memberikan perhatian khusus pada kesalahan siswa.

Kedua, korektisitas dalam pembelajaran sintaksis difokuskan pada korelasi struktur bahasa Ibu terhadap bahasa Arab. Sebagai contoh, dalam bahasa Indonesia atau bahasa Jawa memiliki satu pola dalam pembentukan kalimat dan pada umumnya diawali dengan bentuk kata benda. Kata benda ini berfungtor sebagai Subjek. Sedangkan, dalam bahasa Arab ada struktur yang diawali dengan kata kerja atau berfungtor Predikat.

Ketiga, korektisitas dalam pembelajaran semantik menekankan pada makna. Dalam bahasa Indonesia secara umum setiap kosa kata dasar memiliki satu makna ketika sudah berada dalam satu kalimat. Berbeda dengan bahasa Arab, ada istilah musytarak (satu kata memiliki banyak arti) dan taradif (sinonim). Dalam hal ini, guru harus bisa memberikan solusi yang tepat dalam pembelajaran bahasa agar siswa mampu memahami maksud dari ungkap-ungkapan bahasa Arab yang struktur kalimat disesuaikan dengan kontek bahasa aslinya.

c. Bertahap (ad-darjiyyah)

Prinsip bertahap dalam sebuah pembelajaran bahasa memiliki 3 katagori, yaitu: pertama, penjelasan dari yang konkret ke yang abstrak, dari yang global ke yang detail, dari yang sudah diketahui ke yang belum 
diketahui. Kedua, adanya kesinambungan antara yang sudah dipelajar dan yang akan dipelajari. Ketiga, adanya peningkatan muatan materi dan durasi pembelajaran yang sudah diajarkan dan yang akan diajarkan.

d. Kerinduan belajar (at-tasywiq)

Prinsip ini memiliki arti, bahwa pembelajaran bahasa Arab diharapkan mampu menghadirkan berbagai macam metode pembelajaran. Dengan metode ini akan menjadikan proses pembelajaran menyenangkan dan tidak membuat siswa bosan. Dengan usaha seperti ini diharapkan motivasi akan timbul dari diri siswa untuk belajar bahasa. Hakikat belajar bahasa Arab adalah membentuk suatu kebiasaan yang baru dalam istima' (mendengar), kalam (berbicara), qiroah (membaca), dan kitabah (menulis).

\section{Pembelajaran Bahasa Yang Efektif}

Belajar merupakan sebuah aktifitas perubahan tingkah laku seseorang secara berkelanjutan. Menurut Brown, belajar adalah aktifitas untuk memperoleh atau mendapatkan pengetahuan tentang suatu subjek atau keterampilan melalui studi, pengalaman, atau pembelajaran (Asrori, 2014). Sedangkan, pembelajaran adalah suatu upaya pendidik untuk membelajarkan peserta didik belajar (Tim Pengembang MKDP, 2011). Senada dengan undangundang no. 20 tahun 2003 yang menerangkan bahwa pembelajaran merupakan proses interaksi antara peserta didik dengan pendidikan dan sumber belajar pada lingkungan belajar. Kegiatan pembelajaran termasuk dalam proses pendidikan yang memberikan kesempatan untuk para peserta didik dalam mengembangkan potensi yang dimilikinya, meliputi potensi sikap, pengetahuan, dan keterampilan. Perkembangan potensi secara berangsur-angsur akan menjadi suatu kemampuan. Kemampuan ini yang pada akhirnya akan menjadi bekal dalam menjalankan kehidupan.

Terdapat dua istilah yang sering digunakan dalam teori bahasa, yakni perolehan bahasa dan pembelajaran bahasa. Perolehan bahasa terkait dengan bahasa pertama yang digunakan oleh pengguna bahasa atau bisa disebut bahasa Ibu. Sedangkan, pembelajaran bahasa beorientasi kepada bahasa kedua atau setelah pengguna bahasa mapan dalam penggunaan bahasa pertama. Menurut Krashen, pembelajaran bahasa merupakan kegiatan yang berlangsung dengan sadar untuk penguasaan suatu bahasa (Asrori, 2014). Perkembangan pembelajaran bahasa Arab berdasarkan atas teori-teori ilmu jiwa (psikologi) dan ilmu bahasa (linguistik). Psikologi mengurai kaitannya dengan bagaimana 
seseorang belajar sesuatu (bahasa), sedangkan, linguistik mengkaji tentang seluk beluk bahasa. Kedua kajian ilmu diramu menjadi suatu metode yang memudahkan proses belajar mengajar (Fuad Effendy, 2005). Jadi, pembelajaran bahasa dapat diartikan proses interaksi peserta didikan dan pendidikan untuk mengembangkan kemampuan berbahasa dalam lingkungan belajar.

Proses pembelajaran ini akan tercapai tujuan bilamana dilakukan secara efektif. Menurut Brata, pembelajan yang efektif adalah pembelajaran yang mampu membentuk moralitas dan kebiasaan peserta didik yang dilakukan secara berulang-ulang, perbuatan tersebut dilakukan atas dasar senang hati (Supardi, 2013). Pembelajaran efektif adalah suatu pembelajaran dimana tujuan pembelajaran yang telah dirumuskan dapat diterapkan dalam proses pembelajaran (Saefuddin, 2014). Pembelajaran efektif merupakan klaborasi antara beberapa unsur, diantaranya unsur manusiawi serta materi, media, dan prosedur pembelajaran. Dari unsur tersebut diarahkan untuk mengubah prilaku pesert didik ke arah yang positif sesuai dengan potensi yang dimilikinya dalam mencapai tujuan pembelajaran yang dirumuskan.

Pembelajaran efektif memiliki prinsip-pripsip yang harus diperhatikan, yakni adanya 1) perhatian, 2) motivasi, 3) keaktifan, 4) interaksi langsung, 5) pengulangan, 6) tantangan, 7) balikan, dan 8) perbedaan individual (Uno, 2014). Memperhatikan prinsip-prisip tersebut, faktor keberhasilan dalam pembelajaran efektif meliputi faktor internal peserta didik dan pendekatan pembelajaran. Untuk menumbuhkan sikap seperti itu maka diperlukan kemampuan guru dalam pengelolaan pembelajaran tersebut dengan baik. Pengelolaan ini dapat berupa bagaimana seorang guru memilih teknik, metode, pendekatan, bahkan program pembelajaran yang disesuaikan dengan potensi atau kemampuan peserta didik dengan tetap berpijak pada tujuan pembelajaran.

Berbicara masalah efektifitas pembelajaran bahasa, maka tidak terlepas dari bagaimana tecapainya tujuan pembelajaran secara optimal sesuai dengan program yang telah ditetapkan. Dalam pembelajaran bahasa Arab yang ideal diharapkan siswa mampu menguasahi keterampilan-keterampilan bahasa yang meliputi; keterampilan mendengar, berbicara, membaca, dan menulis. 


\section{Komunikasi-Produktif}

a. Berbicara sebagai Komunikasi-Produktif

Dalam memperoleh keterampilan berbahasa, biasanya melalui suatu hubungan urutan yang teratur; mula-mula, pada masa kecil, kita belajar menyimak/ mendengarkan bahasa, kemudian berbicara, sesudah itu belajar membaca dan menulis (Tarigan, 2008) Dalam menyalurkan gagasan dan perasaan bahasa yang digunakan dapat berupa ujaran untaian kata-kata atau coretan di atas kertas. Keterampilan melakukan keduanya lazim disebut sebagai keterampilan berbicara (al kalam) dan keterampilan menulis (al kitabah).Sebagaimana yang diungkapkan spratt bahwa menulis dan berbicara merupakan kererampilan yang produktif, karena dua hal ini merupakan hasil dari Bahasa tersebut (Spratt, Mary, 2005). senada dengan pendapat spratt, Harmer lebib merinci bahwa Berbicara dan menulis melibatkan produksi bahasa karena itulah sering disebut sebagai keterampilan produktif. Sedangkan Mendengarkan dan Membaca, melibatkan penerimaan pesan maka disebutsebagai keterampilan reseptif (Harmer, 1991). Kedua keterampilan berbahasa ini pada perkembangan selanjutnya dinamakan sebagai keterampilan produktip atau aktif. Para pakar bahasa menamakannya seperti itu kiranya bertolak dari fakta bahwa kedua keterampilan tersebut bisa terwujud dengan usaha aktif melalui alat ucap dan tangan sehingga menghasilkan bahasa yang dapat didengar dan dibaca (produk bahasa) (Sribagus, Sahuddin, 2013).

Berbicara sebagai keterampilan Bahasa produktif Karena dapat digunakan untuk mengekspresikan perasaan pembicara kepada orang lain (Mulyana 2001). Produktivitas dalam hal ini diartikan sebagai keterampilan berbahasa yang paling banyak digunakan untuk berkomunikasi, seiring dengan kemampuan berbahasa lainnya, yaitu menyimak. Tujuan utama berbicara adalah untuk menginformasikan gagasan-gagasan pembicara kepada pendengar. Akan tetapi, tujuan berbicara sebetulnya tidak hanya sebatas memberikan informasi kepada orang lain. Menentukan tujuan berbicara berarti kegiatan berbicara harus ditempatkan sebagai sarana penyampaian sesuatu kepada orang lain sesuai dengan tujuan yang diharapkan pembicara. Berbicara sebagai salah satu bentuk komunikasi dapat digunakan dalam berbagai tujuan. 
Mulyana mengelompokkan tujuan berbicara ke dalam empat tujuan, yaitu tujuan sosial, ekspresif, ritual dan instrumental (Mulyana, 2001). Pertama tujuan sosial Manusia sebagai makhluk sosial menjadikan kegiatan berbicara sebagai sarana untuk membangun konsep diri, eksistensi diri, kelangsungan hidup, memperoleh kebahagiaan dan menghindari tekanan serta ketegangan. Dengan bahasa, manusia dapat menunjukkan siapa dirinya. Orang yang tidak berkomunikasi, cenderung tidak memahami siapa diri sesungguhnya dan bagaimana peran sebagai makhluk social. Kedua tujuan ekspresif Bahasa dapat digunakan untuk mengekspresikan perasaan pembicara kepada orang lain. Ekspresi dalam bentuk bahasa juga dapat terwujud sebagai rasa empati kepada objek yang ada di luar diri pembicara. Ketiga tujuan ritual Kegiatan-kegiatan ritual sering menggunakan bahasa sebagai media untuk menyampaikan pesan-pesan ritual kepada penganutnya. Dalam perayaan hari-hari besar keagamaan tertentu, banyak simbolsimbol keagamaan yang bersifat sakral dituangkan melalui Bahasa, dan keempat tujuan instrumental, dalam tujuan instrumen ini, kegiatan berbicara digunakan sebagai alat untuk memperoleh sesuatu. Sesuatu di sini dapat berupa pekerjaan, jabatan atau hal-hal lainnya.

b. Menulis sebagai Komunikasi-Produktif

Selain berbicara, menulis juga merupakan keterampilan Bahasa produktif. Menulis merupakan keterampilan yang dibutuhkan untuk meningkatkan kualitas berbahasa. Tarigan menjelaskan bahwa menulis ialah menurunkan atau melukiskan lambang-lambang grafik yang menggambarkan suatu bahasa yang dipahami oleh seseorang, sehingga orang lain dapat membaca lambang-lambang grafik tersebut kalau mereka memahami bahasa dan gambaran grafik itu. Dalam hal ini, menulis merupakan kegiatan menuangkan bahasa lisan atau isyarat menjadi bahasa tulis (grafik) sehingga orang menjadi paham maksud dari apa yang disampaikannya.Adanya penguasaan keterampilan menulis, diharapkan dapat mengungkapkan gagasan, pikiran, dan perasaan yang dimilikinya setelah menjalani proses pembelajaran dalam berbagai jenis tulisan, baik fiksi maupun nonfiksi. Menurut Rosidi menulis adalah salah satu bentuk berpikir, yang juga merupakan alat untuk membuat orang lain atau pembaca berpikir. Dengan menulis, 
seseorang mampu mengkonstruk berbagai ilmu atau pengetahuan yang dimilikinya dalam sebuah tulisan, baik dalam bentuk esai, artikel, laporan ilmiah, berita, cerpen, puisi dan sebagainya (Sari, 2016).

Pada dasarnya menulis bertujuan untuk mengungkapkan pikiran, gagasan, dan maksud kepada orang lain secara jelas dan efektif. Setiap tulisan memiliki tujuannya masing-masing, namun secara umum Tarigan mengemukakan tujuan menulis yaitu: a) memberitahukan atau mengajar; b) meyakinkan atau mendesak; c) menghibur atau menyenangkan; d) mengutarakan atau mengekspresikan perasaan atau emosi yang berapi-api (Tarigan, 2008).

\section{Metode}

Sesuai dengan tujuan yang diharapkan dalam artikel ini, maka pendekatan yang dipilih dalam adalah kualitatif deskriptif (Muhadjir, 2002). Pemilihan pendekatan tersebut berdasarkan atas sifat kajian, perspektif teori, sasaran maupun datanya lebih relevan dengan pendekatan kualitatif. Data penelitian yang akan peneliti gali melalui dua tahapan, yaitu; Data collection form human sources, dan data collection from non-human sources. Sumber data jenis pertama teknik pengumpulan data yang digunaka: observasi dan wawancara. Sedang untuk sumber data kedua teknik pengumpulan data yang digunakan adalah dokumentasi.

Dalam penelitian kualitatif the researcher is the key instrument. Peneliti sebagai human instrument berfungsi untuk menetapkan fokus penelitian, memilih informan sebagai sumber data, melakukan pengumpulan data, meneliti kualitas data, analisis data, menafsirkan data dan membuat kesimpulan atas temuannya(Sugiyono, 2006). Untuk menjamin agar data yang diperoleh melalui teknik pengumpulan data wawancara dan observasi dapat dipertanggung jawabkan, maka perlu dilakukan pemeriksaan keabsahan data (trustworthiness), melalui: credebility (kepercayaan), transferability (keteralihan), dependability (kebergantungan), dan confirmability (kepastian).

\section{Pembahasan}

\section{Keterampilan Berbicara Bahasa Arab Siswa}

Untuk mengetahui keterampilan berbicara bahasa Arab Siswa MTs Qudsiyah Putri, peneliti berwawancara dengan guru bahasa Arab dan sekaligus penggagas program Arabic Club pada MTs Qudsiyah Putri, Ustadz Miftahur 
Rahman, M.Pd.I. Beliau menyatakan, bahwa Kemampuan awal Bahasa Arab yang dimiliki oleh siswa Madrasah Tsanawiyah Putri beragam. Keberagaman kemampuan ini berdasarkan output dari berbagai sekolah yang masuk pada madrasah ini. Walaupun lembaga sekolah ini berafiliasi kepada pendidikan keagamaan, belum tentu peminatnya merupakan lulusan dari lembaga pendidikan keagamaan yang berada ditingkat bawahnya, katakanlah dari Madrasah Ibtidaiyah, melainkan juga dari lembaga pendidikan umum setingkat dengan Sekolah Dasar (SD). Untuk meminimalisir kesenjangan kemampuan dan untuk mencapai tujuan pembelajaran bahasa Arab, maka guru bahasa Arab di Madrasah ini memiliki inovasi pengembangan bahasa Arab dalam bentuk program Arabic Club.

Sebelum adanya program Arabic Club, dari keempat keterampilan bahasa yang dimiliki oleh siswa, keterampilan berbicara (كلام) termasuk menempati urutan yang paling bawah. Akan tetapi setelah diadakan program ini, dengan dukungan penuh dari pengurus dan wali murid, kemampuan anak dalam berbahasa semakin meningkat. Ini dibuktikan dengan dengan beberapa indikasi diantaranya; motivasi belajar anak semakin meningkat pada mata pelajaran bahasa Arab; tumbuh percaya diri dalam mengungkapkan ungkapan-ungkapan sederhana; dan nilai akhir semester pada mata pelajaran bahasa Arab sebagian besar siswa mencapai KKM, tambah Ustadz Miftah.

Berdasarkan observasi, pada saat pembelajaran program Arabic Club nampak para siswa antusiasdan aktif mengikuti pembelajaran bahasa Arab. Mereka mengamati dan menyimak materi yang disampaikan oleh guru. Untuk kemampuan berbicara sesekali peneliti melihat siswa berbicara dengan menggunakan bahasa Arab pada saat guru melontarkan sebuah pertanyaan. Bahasa Arab yang mereka gunakan adalah bahasa Arab yang sederhana dalam kontek percakapan sehari-hari. Rata-rata mereka mampu mengungkanpan suatu ungkapan dengan menggunakan kosa kata yang sederhana. Sebagai contoh, mereka mengenal benda-benda yang ada disekitar sekolah dengan menggunakan bahasa Arab. Akan tetapi, mereka belum bisa menggunakan bahasa Arab yang terlalu rumit, karena program Arabic Club ini baru didisain untuk keterampilan bahasa Arab dasar atau untuk para pemula atau dapat diistilahkan untuk tingkatan tamhidi.

Dari hasil wawancara dan observasi, peneli mendapatkan gambaran bahwa kemampuan bahasa Arab terutama pada keterampilan berbicara secara 
umum masih lemah dilihat dari hasil seleksi penerimaan siswa baru dari berbagai sekolah yang beragam. Untuk menjembatani adanya kesenjangan kemampuan siswa dalam mata pelajaran bahasa Arab bagi siswa MTs Qudsiyyah Putri dibuatlah suatu program yang menarik yakni program Arabic Club sebagai ekstrakulikuler yang diikuti oleh siswa baru atau untuk siswa kelas 7. Setelah para siswa mengikuti program ini, nampak perkembangan ke arah positif. Perkembangan terkait sikap anak terhadap mata pelajaran Bahasa Arab yang memunculkan semangat dalam belajar bahasa Arab atau termotivasi. Terkait perkembangan kognitif, setelah mengikuti program ini nilai yang didapat siswa mencapai KKM, disamping mereka bisa menggunakan kalimat yang sederhana dari kosa kata yang ada disekitar lingkungan sekolah dan rumah yang telah dipelajarinya.

Peningkatan kemampuan bahasa Arab siswa MTs Qudsiyah Putri berdampak pula pada hasil belajar siswa tidak hanya pada mata pelajaran bahasa Arab, tapi juga pada mata pelajaran yang lain. Dampak positif ini akan lebih meluas karena banyak mata pelajaran dalam madrasah ini yang bersumber kitab salaf atau kitab kuning. Bahasa Arab merupakan bahasa sumber yang ada dalam kitab salaf tersebut. Jadi, program Arabic Club yang ada pada madrasah ini bukan dikembangkan untuk meningkatkan kemampuan hasil belajar mata pelajaran bahasa Arab secara khusus, akan tapi memberikan penguatan pemahaman terhadap kitab salaf yang menjadi icon dari madrasah ini pada umumnya.

\section{Implementasi Program Arabic Club}

Program Arabic Club secara harfiyah memiliki arti perkumpulan Arab. Ini bermaksud suatu perkumpulan yang terdiri dari siswa-siswa dalam pembelajaran bahasa Arab dengan mencoba bahasa Arab sebagai bahasa Pengantar. Program ini untuk membantu para siswa yang masih kesulitan dalam pembelajaran bahasa Arab pada kelas formal. Program ini juga untuk menambah motivasi belajar bahasa Arab bagi mereka yang sebelumnya pernah belajar bahasa Arab pada tingkat SD/MI. Program ini juga bisa dikatakan program kursus yang diikuti oleh semua siswa kelas tujuh di MTs Qudsiyyah Putri. Program ini termasuk program informal yang dilakukan di luar jam sekolah. Meskipun bukan termasuk program formal namun dalam pelaksanaannya menyesuaikan kurikulum formal yang diterapkan di madrasah.

Ada tiga kegiatan dalam implementasi Program Arabic Club yakni, perencanaan, pelaksanaan, dan evaluasi. Kegiatan perencanaan memiliki fungsi 
sebagai acuan dan gambaran dalam proses pembelajaran agar dapat berjalan sesuai capaian pembelajaran secara menyeluruh. Perencanaan menjadi suatu prasyarat untuk mencapai tujuan secara sistematis dan optimal.

Menurut ustadz Miftahur Rahman, perencanaan Program Arabic Club dibuat sederhana dan bersifat fleksibel. Perencanaan ini dibuat melalui rapat dewan guru, namun secara administratif belum terbukukan selengkap seperti yang ada dalam RPP dan Silabus. Perencanaan program ini meliputi; muatan materi, tujuan pembelajaran, metode pembelajaran, dan evaluasi pembelajaran. Terlebih terkait dengan pembelajaran bahasa pada keterampilan berbicara perlu adanya perencanaan yang cermat. Hal ini menjadi penting agar siswa berani mengungkapkan ujaran, bertanya, tidak malu-malu dan berani menggunakan bahasa Arab. Sifat fleksibel ini yang membuat pengajar Program Arabic Club bisa menggunakan perangkat pembelajaran secara bebas sesuai kondisi yang dihadapi pada saat itu, tetap berpedoman pada pencapaian.

Terkait pelaksanaan Program Arabic Club dilakukan secara terjadwal dan terstruktur dengan muatan materi disesuaikan dengan kurikulum formal. Program ini diselenggarakan pada hari Senin jam 14.00-15.30 selepas KBM dan diikuti semua siswa kelas 7 MTs Qudsiyyah Putri dan dibagi menjadi kelompokkelompok.

Dalam proses pembelajaran bahasa asing agar menjadi mudah, maka dibutuhkan metode yang bisa menggugah keaktifan siswa dalam berkomunikasi. Disamping itu juga, metode yang menyenangkan akan lebih mudah untuk memperlancar penyerapan materi oleh siswa. Beberapa metode yang digunakan dalam pembelajaran program ini adalah Audio-lingual, qawaidtarjamah, langsung, dan metode situasional.

Sebagai contoh pembelajaran dengan metode Audio-lingual. Pada metode ini guru menggunakan dua sistem. Sistem pertama pembelajaran dilakukan di dalam ruangan (indoor), sistem kedua di luar ruangan (outdoor). Teknik yang digunakan guru dalam pembelajaran di ruang adalah menyanyikan beberapa lagu terkait materi yang disampaikan. Sebagai contoh materi tentang Warna (الألوان) guru menyanyikan lagu yang kemudian ditirukan oleh para siswa.

\begin{tabular}{|c|c|}
\hline أَحْمَرْ & Merah \\
\hline أَبْيَضْن & Putih \\
\hline أَسْنَوَد & Warna hitam \\
\hline
\end{tabular}




\begin{tabular}{|c|c|}
\hline أَصْفَرْ & Kuning \\
\hline أَزَزَقْهُ & Biru \\
\hline أَرْمَدْ & Abu-abu \\
\hline أَسْنَمَ & Coklat \\
\hline أَخْضَرْ & Hijau \\
\hline بِنَفْسَجِيْ & Unggu \\
\hline
\end{tabular}

Setelah dirasa para siswa sudah hafal lagu tersebut, kemudia dilanjut pembelajaran dengan sistem kedua. Dalam sistem ini guru mempersilahkan para siswa untuk keluar ruangan. Ada yang berada di teras kelas dan ada di lapangan, ada juga yang berdiri dan sebagian ada yang duduk dengan membawa selembar kertas dan sebuah alat tulis. Teknik yang digunakan adalah mendata kosa kata yang sesuai dengan materi yang telah diajarkan di dalam ruangan tadi. Tidak hanya mendata kosa kata berbahasa Arab, mereka juga harus menghafalkannya. Dengan waktu yang singkat apa yang mereka tulis sebagian besar mereka hafal dan mampu mempraktikannya dalam kalimat sederhana. Kemampuan ini bisa dilihat pada saat akhir pembelajaran dengan cara guru memberikan pertanyaan secara lisan, mereka dengan cepat bisa menjawabnya.

Yang terakhir terkait evaluasi program Arabic Club yang dilaksanakan di MTs Qudsiyyah Putri bersifat penilai sumatif. Guru memberikan penilaian terhadap hasil belajar siswa pada akhir unit atau materi pembelajaran. Guru memberikan beberapa soal yang harus dikerjakan untuk mengetahui kemampuan siswa sebelum menlanjutkan atau berpindah dari satu unit satu ke unit selanjutnya. Pada akhir semester juga guru melakukan penelaian sumatif dengan mencantumkan soal-soal dari beberapa pokok bahasan yang telah dipelajaran untuk mengetahui tingkat ketercapaian dalam satu semester. Evaluasi pembelajaran dilakukan secara formal dengan memberikan tes secara lisan, tulisan, dan praktek.

\section{Faktor Pendukung dan Penghambat}

Dalam perjalan suatu program pasti ada faktor pendukung dan penghambat, seperti itu juga dalam program Arabic Club. Faktor pendukung dalam pengembangan kemampuan bahasa produktif-komunikatif pada MTs Qusiyyah Putri meliputi:

a. Tersedianya guru atau tenaga pengajar yang mumpuni dan memiliki kualifikasi pendidikan bahasa Arab. Sehingga proses pembelajaran berjalan dengan lancar. 
b. Dukungan dari pihak madrasah dan wali siswa yang sangat kuat akan keberadaan program Arabic Club dalam mengembangkan kemampuan bahasa Arab. Antara pihak madrasah dan wali santri saling memahami seberapa pentingnya belajar bahasa, terutama bahasa yang digunakan dalam sumber agama yakni bahasa Arab.

c. Semangat siswa dalam mengikuti pembelajaran bahasa Arab di kelas formal. Mereka merasa lebih siap menerima pembelajaran di dalam kelas karena sudah memiliki modal dari pembelajaran ekstra kulikuler pada program Arabic Club. Semangat ini terbukti pada saat pembelajaran bahasa Arab di kelas formal mereka dengan seksama memperhatikan dan mendengarkan apa yang diterangkan oleh guru.

d. Latar belakang keluarga atau sosial dari siswa sangat menunjang keberhasilan pembelajaran bahasa Arab. Disamping tersedianya fasilitas belajar seperti buku dan kamus, fasilitas yang ada di rumah juga bisa menjadi support akan penguasaan kosa kata. Benda-benda yang dapat menambah kosa kata siswa, misalnya kendaraan, TV, sofa, meja, komputer, dan sebagainya.

Hambatan yang ditemukan dalam proses pembelajaran pada program Arabic Club pada siswa MTs Qudsiyyah Putri adalah sebagai berikut;

a. Bahan ajar yang masih sangat sederhana. Ini dibuktikan dengan program Arabic Club belum mempunyai modul sendiri yang dapat digunakan. Bahan ajar masih berupa buku dan Lembar Kerja Siswa (LKS) bahasa Arab yang digunakan pada kelas formal. Dengan modul yang disesuaikan dengan kemampuan siswa akan menjadikan belajar lebih mudah.

b. Sarana atau media pembelajaran masih kurang memadahi. Pembelajaran bahasa Arab akan lebih efektif manakala sara penunjang terpenuhi karena siswa akan lebih senang dengan sesuatu yang bersivat virtual. Penggunaan media ini bisa berupa gambar, miniatur, dan pupper yang bisa menarik dan menyenangkan dalam membantu penyampaian materi.

c. Tidak adanya pembiasaan penggunaan bahasa Arab di luar mata pelajaran bahasa Arab. Ketika selesai pembelajaran bahasa Arab, maka para siswa kembali menggunakan bahasa ibu mereka masing-masing. Terlebih apa bila mereka sudah berada di rumah, nyaris mereka tidak mempraktikan bahasa Arab untuk berkomunikasi dengan anggota keluarga. 


\section{Simpulan}

Program Arabic Club merupakan program yang diselanggarakan oleh MTs Qudsiyyah Putri yang bertujuan untuk meningkatkan kemampun bahasa Arab siswa. Keberadaan program semacam kursus ini memberikan suasana yang positif dalam pembelajaran bahasa Arab pada kelas Formal. Keberadaan program Arabic Club sebagai penguat ketercapaian pembelajaran mata pelajaran bahasa Arab yang sesuai dengan kurikulum formal. Kemampuan siswa pertama kali masuk di kelas tujuh beragam. Keberagaman itu disebabkan dari berbagai sekolah/madrasah asal. Setelah adanya program Arabic Club siswa yang semula sudah memilki bekal bahasa Arab siswa tersebut semakin percanya diri ketika belajar pada mata pelajaran Bahasa Arab. Sedangkan yang masih siswa yang masih kurang penguasaan terhadap bahasa Arab sedikit demi sedikit bisa mengikuti pembelajaran bahasa Arab di kelas formal. Program Arabic Club sebagai sumplement bagi siswa dalam pembelajaran bahasa Arab dengan prinsif belajar yang mudah dan menyenangkan. Walaupun dengan prinsip mudah dan menyenangkan tapi tetap berpedoman pada tujuan pembelajaran. Program Arabic Club di MTs Qudsiyyah Putri memiliki faktor pendukung dan faktor penghambat. Faktor pendukung ada yang bersifat intern dan ekstren. Pendukung yang bersifat intern meliputi semangat atau motivasi belajar, eksternal meliputi kemampuan guru, daya dukung dari lingkungan madrasah dan keluarga. Faktor penghambat bersifat eksternal, yang meliputi bahan ajar, media, dan lingkungan di luar madrasah yang kurang mendukung. 


\section{Daftar Pustaka}

Asrori, Imam. 2014. Strategi Belajar Bahasa Arab: Teori Dan Praktek. Malang: Misykat.

Fuad Effendy, Ahmad. 2005. Metodologi Pengajaran Bahasa Arab. Malang: Misykat.

Harmer, Jeremy. 1991. The Practice of Language Teaching. London: Longman.

Muhadjir, Noeng. 2002. Metodologi Penelitian Kualitatif. Yogyakarta: Andi Ofset.

Mulyana, Deddy. 2001. Ilmu Komunikasi: Suatu Pengantar. Bandung: Remaja Rosda Karya.

Rosyidi, Abd Wahab \& Mamluatul Ni'mah. 2012. Memahami Konsep Dasar Pembelajaran Bahasa Arab. Malang: UIN- Maliki Press.

Saefuddin, Asis dan Ika Berdiati. 2014. Pembelajaran Efektif. Bandung: PT. Remaja Indonesia.

Sari, Santika Damayanti . DKK. 2016. "Peningkatan Keterampilan Menulis Teks Berita Melalui Model Think Talk Write Dengan Pemanfaatan Media Kliping Foto Jurnalistik Pada Siswa Kelas Viii C Smp Negeri 8 Batang." JPBSI 5 (1).

Spratt, Mary, et al. 2005. The Teaching Knowledge Test Course. New York: Cambridge University Press.

Sribagus, Sahuddin, L. Nurtaat. 2013. "Beda Dan Sama Dalam Keterampilan Produktif: Satu Kemungkinan Perpaduan Silabus." Jurnal Kependidikan IKIP Mataram 12 (2).

Sugiyono. 2006. Metodologi Penelitian Pendidikan: Pendekatan Kuantitatif, Kualitatif, Dan R\&D. Bandung: Alfabeta.

Supardi. 2013. Sekolah Efektif. Jakarta: PT Grafindo Persada.

Tarigan, H.T. 2008. Membaca Sebagai Suatu Keterampilan Berbahasa. Bandung: Angkasa.

Tim Pengembang MKDP. 2011. Kurikulum \& Pembelajaran. Jakarta: Rajawali Press. 
Uno, Hamzah B. \& Nurdin Muhammad. 2014. Belajar Dengan Pendekatan PAILKEM. Jakarta: Bumi Aksara.

Wahab, Muhbib Abdul. 2008. Epistimologi Dan Metodologi Pembelajaran Bahasa Arab. Jakarta: Lembaga Penelitian UIN Syarif Hidayatullah. 